\title{
2021 Handbook of Florida Water Regulation: Appendix ${ }^{1}$
}

\author{
Michael T. Olexa, Tatiana Borisova, and Jana Caracciolo²
}

\section{Preface}

This handbook is designed to provide an accurate, current, and authoritative summary of the principal federal and state (Florida) laws that directly or indirectly relate to agriculture. This handbook provides a basic overview of the many rights and responsibilities that farmers and farmland owners have under both federal and state laws as well as the appropriate contact information to obtain more detailed information. However, the reader should be aware that because the laws, administrative rulings, and court decisions on which this handbook is based are subject to constant revision, portions of this publication could become outdated at any time. Several details of cited laws are also left out due to space limitations. This handbook is provided as an educational text for those interested in water use and water resource issues in Florida.

This handbook is distributed with the understanding that the authors are not engaged in rendering legal or other professional advice, and the information contained herein should not be regarded as a substitute for professional advice. This handbook is not all inclusive in providing information to achieve compliance with the federal and state laws and regulations governing water protection. For these reasons, the use of these materials by any person constitutes an agreement to hold harmless the authors, the UF/IFAS Center for Agricultural and Natural Resource Law, and UF/IFAS Extension for any liability claims, damages, or expenses that may be incurred by any person as a result of reference to or reliance on the information contained in this handbook. Note: UF/IFAS is the acronym for University of Florida, Institute of Food and Agricultural Sciences.

\section{List of Acronyms}

The following is a list of acronyms for the Handbook of Florida Water Regulation (FE579 - FE617, FE1017-FE1019)

ACE_-United States Army Corp of Engineers

BMAP_Basin Management Action Plan

BMP_Best Management Practice

BRA—Florida Brownfields Redevelopment Act

CAFO_Concentrated Animal Feeding Operations

CERCLA-Comprehensive Environmental Response, Compensation, and Liability Act (or Superfund)

CERP_Comprehensive Everglades Restoration Program

CWA-Clean Water Act

1. This document is FE615, one of a series of the Food and Resource Economics Department, UF/IFAS Extension. Original publication date October 1998. Revised June 2017 and April 2021. Visit the EDIS website at https://edis.ifas.ufl.edu for the currently supported version of this publication.

2. 2.Michael T. Olexa, professor, Food and Resource Economics Department, and director, UF/IFAS Center for Agricultural and Natural Resource Law; Tatiana Borisova, associate professor, Food and Resource Economics Department; and Jana Caracciolo, student, Levin College of Law; UF/IFAS Extension, Gainesville, FL 32611.

The Institute of Food and Agricultural Sciences (IFAS) is an Equal Opportunity Institution authorized to provide research, educational information and other services

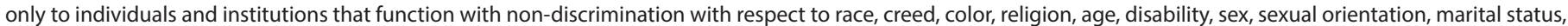

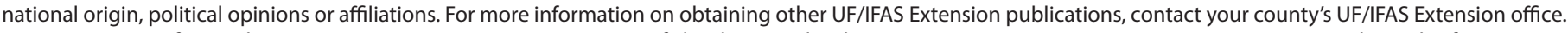
U.S. Department of Agriculture, UF/IFAS Extension Service, University of Florida, IFAS, Florida A \& M University Cooperative Extension Program, and Boards of County Commissioners Cooperating. Nick T. Place, dean for UF/IFAS Extension. 
EAA—Everglades Agricultural Area

ECP_Everglades Construction Project

EPA-Environmental Protection Agency

EPCRA-Emergency Planning and Community Right-toKnow Act

ERC_Environmental Regulation Commission

ESA-Endangered Species Act

FAC_Florida Administrative Code

FARMS-Facilitating Agricultural Resource Management Systems

FAWPCA-Florida Air and Water Pollution Control Act

FCPTF_Florida Coastal Protection Trust Fund

FDACS-Florida Department of Agriculture and Consumer Services

FDEM-Florida Division of Emergency Management

FDEP_Florida Department of Environmental Protection

FDOH-Florida Department of Health

FEFA-Florida Everglades Forever Act

FEPCRA-Florida Emergency Planning and Community Right-to-Know Act

FFWCC_-Florida Fish and Wildlife Conservation Commission

FIFRA—Federal Insecticide, Fungicide, and Rodenticide Act

FLOPP_Florida Lake Okeechobee Protection Plan

FPDPCA—Florida Pollution Discharge Prevention and Control Act

FPL_Florida Pesticide Law

FRTFA-Florida Right-To-Farm Act

FSAPA-Florida Springs and Aquifer Protection Act
FSHMERC_Florida State Hazardous Materials Emergency Response Commission

FQPA—Food Quality Protection Act

FWMD—Florida Water Management Districts

FWPCA-Federal Water Pollution Control Act

FWRA-Florida Watershed Restoration Act

HRS—Hazard Ranking System

IPM-Integrated Pest Management

LEPC_Local Emergency Planning Committee

LOWCP_Lake Okeechobee Watershed Construction Project

MSSW-Management and Storage of Surface Waters

NEEPP—Northern Everglades and Estuaries Protection Program

NEPA - National Environmental Policy Act

NIOSH-National Institute for Occupational Safety and Health

NPDES-National Pollutant Discharge Elimination System

NRCS—Natural Resources Conservation Service

OAWP-Office of Agricultural Water Policy

OFS-Outstanding Florida Springs

OSTDS-Onsite Sewage Treatment and Disposal System

PIR_Project Implementation Report

PRC_-Pesticide Review Council

RCRA-Resource Conservation and Recovery Act

SARA-Superfund Amendments and Reauthorization Act

SCS—Soil Conservation Service

SDWA-Safe Drinking Water Act

SERC-State Emergency Response Commission 
SFWMD—South Florida Water Management District

SQG_Small Quantity Generator

STA-Stormwater Treatment Areas

SWCD—Soil and Water Conservation District

SWIM-Surface Water Improvement Management

TCNS-Taylor Creek/Nubbin Slough Reservoir and

Treatment Area Project

TMDL_-Total Maximum Daily Loads

TSCA-Toxic Substances Control Act

UIC-Underground Injection Control

USDA-United States Department of Agriculture

WMD_Water Management District

WPS-Watershed Protection Section

WQS-Water Quality Standards

\section{Acknowledgments}

The authors are indebted to the personnel of both state and federal agencies who provided their time and advice in the preparation of this handbook. We acknowledge Carol Fountain and Susan Gildersleeve at the University of Florida for their assistance in editing this handbook. We also acknowledge funding received for updating this publication from the James S. and Dorothy F. Wershow Agricultural Law Endowment. 